\title{
Comparison of the Bacterial Microbiota in a Bale of Collected Cardboard Determined by 454 Pyrosequencing and Clone Library
}

\author{
Valérie Lalande ${ }^{1,2 *}$, Simon Barnabé ${ }^{3}$ Jean-Charles Côté ${ }^{2}$ \\ ${ }^{1}$ Département de Biologie Médicale, Université du Québec à Trois-Rivières, Trois-Rivières, Canada \\ ${ }^{2}$ Agriculture and Agri-Food Canada, Research and Development Centre, Saint-Jean-sur-Richelieu, Canada \\ ${ }^{3}$ Département de Chimie, Biochimie et Physique, Université du Québec à Trois-Rivières, Trois-Rivières, Canada \\ Email: Valerie.Lalande@uqtr.ca
}

Received 21 June 2014; revised 24 July 2014; accepted 22 August 2014

Copyright (C) 2014 by authors and Scientific Research Publishing Inc.

This work is licensed under the Creative Commons Attribution International License (CC BY). http://creativecommons.org/licenses/by/4.0/

\section{(c) (i) Open Access}

\begin{abstract}
Biofouling, the accumulation of microorganisms, is a major problem in paper mills processing paper and cardboard. This leads to the production of lower quality recycled products. Several studies have focused on the microbial content in the paper mill and the final products. Our aim was to determine the microbial biota in a bale of collected cardboard prior to entering the paper mill. Total genomic DNA was isolated and analyzed using two different methods for comparison purposes: 454 pyrosequencing and clone library. A total of $3268 \mathrm{V6}-\mathrm{V8} 454$ pyrosequencing reads and 322 cloned V6-V8 16S rRNA nucleotide sequences were obtained. Both methods showed the presence of three major bacterial genera: Bacillus, Solibacillus and Paenibacillus, all members of the spore-forming phylum Firmicutes. Pyrosequencing, however, revealed a richer and more diverse bacterial community than clone library. It showed the presence of additional minor Firmicute genera and of a small number of Proteobacteria. The sorting at the recycling plant, the storing, and the processing at the paper mill, the end uses, will all contribute to the bacterial microbiota present in a bale of collected cardboard as revealed here.
\end{abstract}

\section{Keywords}

454 Pyrosequencing, Bacterial Microbiota, Cardboard, Clone Library, Paper Mill

\footnotetext{
${ }^{*}$ Corresponding author.
} 


\section{Introduction}

In a paper mill, collected paper and cardboard obtained from a recycling plant are mixed with water to form a fiber slurry. The slurry is passed through fine mesh screens, leaving sheets of wet paper and cardboard fibers on the screens, and white water, water with cloudy appearance due to the presence of fibers. The former are further dried and processed to yield the final recycled products. Owing to the large volumes of water used, the latter is re-circulated in the treatment of additional bales of collected paper and cardboard.

Bales of collected paper and cardboard, owing to their high cellulose content, provide a substrate for microbial growth during storage and processing [1] [2]. Moreover, because the white water has been enriched in cellulose and residual sugars through multiple reuses, it is a suitable substrate for microbial proliferation. These lead to the formation of biofilms, the clogging of pipes and the corrosion of equipment. Biocides can be used to control the microbial contamination. This, however, is not without drawbacks. Biocides are costly and eventually released in the environment where they cause negative impacts. Plant downtime for cleaning can occur and, in some cases, the quality of the final recycled paper and cardboard can be much lowered as evidenced by the presence of bacteria, holes, pores, undesirable odor, and decreased mechanical strength [3].

A better knowledge of the microbial contamination source is necessary to control the problems caused by the accumulation of microorganisms, biofouling, and to increase the quality of the final recycled paper and cardboard [4]. Culturable bacterial population diversity has been studied in the fiber slurry [5]-[7], white water [5] [8], biofilms [6] [9] [10], and the final recycled products [11] by 16S rRNA gene sequences. In addition, biofilms were also studied by microscopy [5] [9] [10] [12], physiological and biochemical characterization [9] [10] [12], and fatty acids analysis [10] [12]. Unculturable bacterial population diversity has been determined in the fiber slurry [13] [14], white water [14] and biofilms [13]-[15] by 16S rRNA gene sequences.

One of the most important sources of bacterial contamination in a paper mill is the cellulosic raw material [2]. However, the microbiota present in bales of collected paper and cardboard has never been characterized.

The characterization of bacterial populations traditionally relied on cultures followed by sequencing the $16 \mathrm{~S}$ rRNA gene, the nucleotide sequence of choice in bacterial identification [16]. Most bacteria, however, cannot be cultivated [17]. Metagenomics is the study of the entire genetic material present in a sample. Here, total DNA is isolated and a 16S rRNA clone library is prepared. The nucleotide sequence of each clone is determined. More recently, high-throughput massively parallel pyrosequencing has revolutionized environmental microbiology [18]. It permits the direct sequencing of the amplified target DNA, bypassing the need for cloning.

Our aim in the present preliminary study was to determine the bacterial microbiota in a single bale of collected cardboard, prior to entering the paper mill. Two different approaches were used: 454 pyrosequencing and clone library.

\section{Materials and Methods}

\subsection{Sampling}

A bale of collected cardboard of $1.8 \mathrm{~m} \times 0.7 \mathrm{~m} \times 1.2 \mathrm{~m}$ in size was obtained from a recycling plant (QC, Canada). Fifteen samples of approximately 20 g each were randomly collected from the bale using a high-speed hole cutter (3.5 cm in diameter) coupled to an electric drill. They were pooled together, transferred in a plastic bag and frozen at $-80^{\circ} \mathrm{C}$ until use.

\subsection{Total Genomic DNA Extraction}

A 10 g cardboard sample was transferred in a $1 \mathrm{~L}$ flask containing $125 \mathrm{ml}$ saline $(0.85 \% \mathrm{NaCl})$ and incubated on a rotary shaker at $120 \mathrm{rpm}$, at room temperature, overnight. A $12 \mathrm{ml}$ volume of mixture was transferred to a 15 $\mathrm{ml}$ tube, centrifuged in a Beckman-Coulter Allegra $25 \mathrm{R}$ Centrifuge tabletop at $1000 \mathrm{rpm}, 3 \mathrm{~min}$, at room temperature, to pellet the fibers. The supernatant was transferred to a $50 \mathrm{ml}$ tube, centrifuged in a Beckman (Model $\mathrm{J} 2-21 \mathrm{M})$ at $9000 \mathrm{rpm}, 15 \mathrm{~min}$, at room temperature, to pellet the cells. The supernatant was discarded and the cell pellet resuspended in $480 \mu \mathrm{l} 50 \mathrm{mM}$ EDTA pH 8.0. Total genomic DNA was isolated using the Wizard DNA Purification Kit (Promega, Madison, WI, USA) according to the manufacturer's instructions for "Isolating Genomic DNA from Gram Positive and Gram Negative Bacteria”.

\subsection{PCR Amplification of the 16 S rRNA Gene V6-V8 Region and 454 Pyrosequencing}

Two separate PCR amplifications were performed; a first one in which the amplicons were sequenced on a 
Roche 454 GS-FLX Titanium platform, a second one in which the amplicons were cloned and sequenced.

The 16S rRNA gene V6-V8 region was amplified with the primer pair used for 454 pyrosequencing A1B969F (5'-CCATCTCATCCCTGCGTGTCTCCGACTCAG·ACGAGTGCGT·ACGCGHNRAACCTTACC-3') and B-BA1406R (5'-CCTATCCCCTGTGTGCCTTGGCAGTCTCAG'ACGGGCRGTGWGTRCAA-3') as designed by Comeau et al. [19]. The forward primer included Roche's A adaptor, a multiplex identifier and the 16S rRNA gene V6 specific primer. This primer corresponds to nucleotide positions 969 to 985 in the $E$. coli 16S rRNA gene. The reverse primer included Roche's B adaptor and the 16S rRNA gene V8 specific primer. It corresponds to nucleotide positions 1390 to 1406 .

The amplification was performed as described by Comeau et al. [19] at the Plate-forme d'Analyses Génomiques (PAG), Institut de Biologie Intégrative et des Systèmes (IBIS), Université Laval, Quebec City, QC, Canada. The amplification conditions were as follows: an initial denaturation at $98^{\circ} \mathrm{C}$ for $30 \mathrm{~s}$, followed by 30 cycles at denaturing temperature of $98^{\circ} \mathrm{C}$ for $10 \mathrm{~s}$, annealing at $55^{\circ} \mathrm{C}$ for $30 \mathrm{~s}$, extension at $72^{\circ} \mathrm{C}$ for $30 \mathrm{~s}$, followed by a final extension at $72^{\circ} \mathrm{C}$ for $5 \mathrm{~min}$.

The nucleotide sequences were determined on a Roche 454 GS-FLX Titanium platform at IBIS. The raw pyrosequencing reads were deposited in the NCBI Sequence Read Archive with accession number SRR961674.

\subsection{PCR Amplification of the 16S rRNA Gene V6-V8 Region, Cloning and Sequencing}

The 16S rRNA gene V6-V8 region was amplified with the primer pair B969F (5'-ACGCGHNRAACCTTACC-3') and BA1406R (5'-ACGGGCRGTGWGTRCAA-3') [19]. A PCR reaction contained $15 \mu \mathrm{l}$ of Top Taq Master Mix (Qiagen Sciences, Germantown, MD, USA), $0.6 \mu$ of each primer and $50 \mathrm{ng}$ of total genomic DNA, in a final volume of $30 \mu \mathrm{l}$. The amplification conditions were as described above. The PCR amplicons were visualized on a $0.7 \%$ agarose gel and stored at $-20^{\circ} \mathrm{C}$.

The PCR amplicons were cloned using a TOPO TA Cloning ${ }^{\circledR}$ Kit (Invitrogen, Carlsbad, CA, USA) according to the manufacturer's instructions. The isolation of recombinant plasmids was performed using a QIAprepSpin Miniprep Kit (Qiagen Sciences) following the manufacturer's instructions. The nucleotide sequences were determined for both strands by the dideoxynucleotide-chain-termination method [20] using a capillary array automated DNA sequencer (ABI3730XL DNA Analyzer, Applied Biosystems, Foster, CA, USA) at the sequencing platform of the McGill University and Génome Québec Innovation Centre, Montreal, QC, Canada. The nucleotide sequences were deposited in GenBank under accession numbers KF589334-KF589827.

\subsection{Sequence Analysis, Taxonomic Identification and Statistics}

Raw 454 pyrosequencing reads and V6-V8 16S rRNA nucleotide sequences obtained following cloning were processed within Mothur v.1.30.0 (http://www.mothur.org) [21] [22] as described by Comeau et al. [23]. Briefly, low-quality pyrosequencing reads and low-quality V6-V8 16S rRNA nucleotide sequences obtained following cloningalong with chimeric sequences were removed. The high-quality reads and nucleotide sequences were aligned against the bacterial SILVA (http://www.arb-silva.de/) [24] reference alignmentand were improved by removing misaligned reads. The singletons were finally excluded to yield the final dataset. These final reads were clustered into Operational Taxonomic Units (OTUs) at the 97\% similarity level, and taxonomic identification of the OTUs was carried out in Mothur against a modified 16S rRNA gene database based upon the “GreenGenes97” (http://greengenes.lbl.gov) [25] [26] reference files for pyrosequencing [23].

The rarefaction curves, the plot of the number of OTUs over the number of sequences sampled, were generated. The Chao 1 richness estimator, the Shannon and Simpson diversity indices, and the evenness were calculated at the $97 \%$ similarity level using Mothur.

\section{Results and Discussion}

\subsection{PCR Amplification of the 16S rRNA Gene V6-V8 Region and 454 Pyrosequencing}

A total of 3268 V6-V8 454 pyrosequencing finalreads was obtained. Their average length was $435 \mathrm{bp}$. At the 97\% similarity level, these reads were clustered into 117 OTUs. As shown in Figure 1(A), 97\% of these OTUs belonged to the phylum Firmicutes. The remaining 3\% belonged to the phylum Proteobacteria. All Firmicutes were assigned to three families: Bacillaceae, Planococcaceae, Paenibacillaceae with $76 \%, 14 \%$ and $7 \%$ of the total OTUs, respectively. These three families comprised six, two, and one genera. The unclassified Bacillaceae 


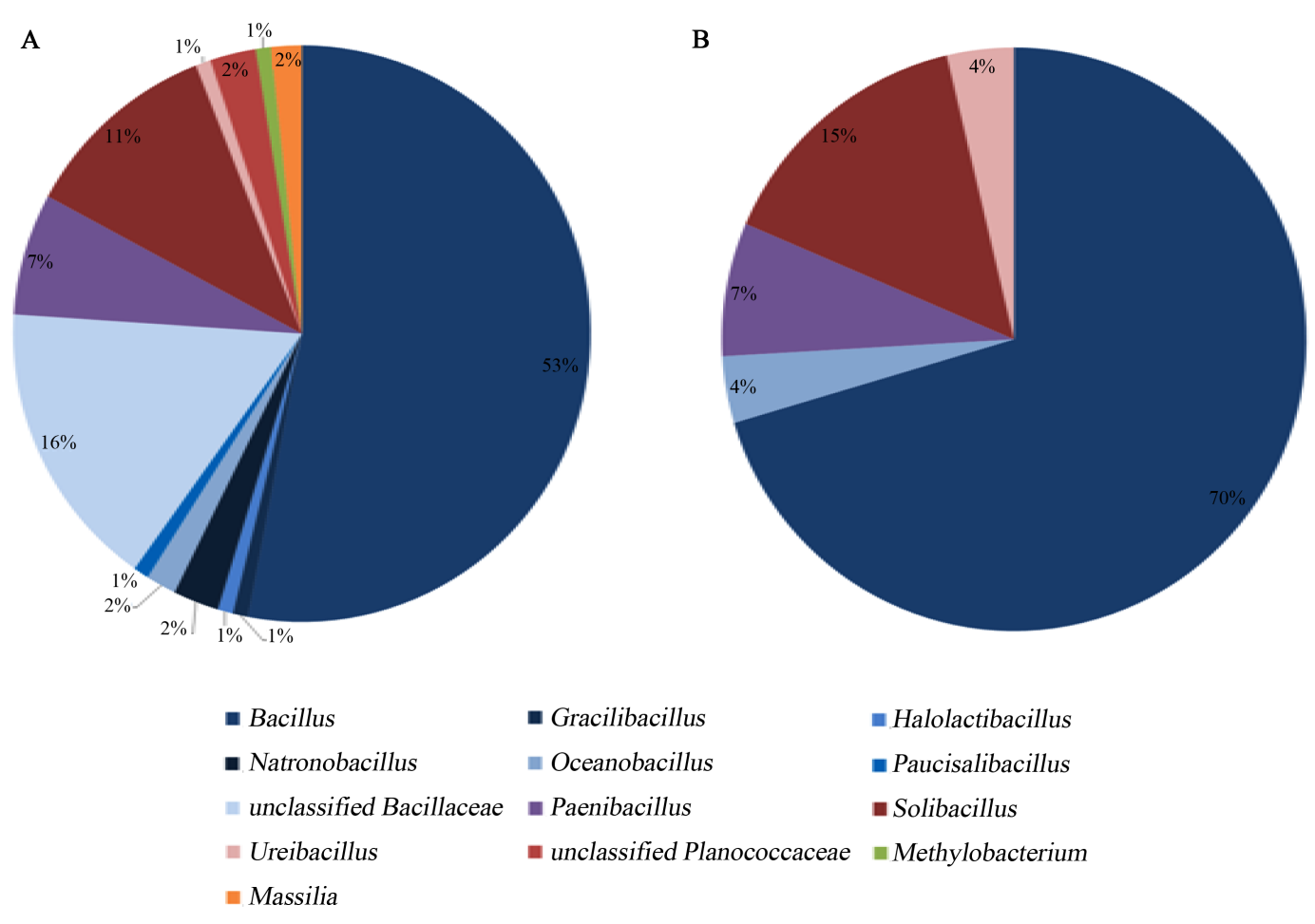

Figure 1. Taxonomic distribution of all bacterialOTUs at the $97 \%$ similarity level. (A) Distribution of bacterial genera obtained from 454 pyrosequencing; (B) Distribution of bacterial genera obtained from clone library.

and Planococcaceae represented $16 \%$ and $2 \%$ of the total OTUs. Interestingly, the genus Bacillus, a member of the Bacillaceae family, accounted for 53\% of the total OTUs. The genera Solibacillus and Paenibacillus, members of the Planococcaceae and Paenibacillaceae families, were also predominantly represented with $11 \%$ and $7 \%$ of the total OTUs.

\subsection{PCR Amplification of the 16S rRNA Gene V6-V8 Region, Cloning and Sequencing}

A total of 494 V6-V8 sequences was obtained. They vary from 436 to 441 bp in length. Following processing, a total of 322 sequences was retained. Their average length was 439 bp. At the $97 \%$ similarity level, these sequences were clustered into 27 OTUs. As shown in Figure 1(B), they all belonged to the phylum Firmicutes. Here also, all Firmicutes were assigned to three families: Bacillaceae, Planococcaceae, Paenibacillaceae with $74 \%, 19 \%$ and $7 \%$ of the total OTUs, respectively. These three families comprised two, two, and one genera. Here also, the genus Bacillus accounted for $70 \%$ of the total OTUs. The genera Solibacillus and Paenibacillus were also predominant with $15 \%$ and $7 \%$ of the total OTUs.

\subsection{Comparison of the Bacterial Communities Obtained Using 454 Pyrosequencing and Clone Library}

The rarefaction curves showed that 454 pyrosequencing yielded more OTUs than clone library when the same number of sequences was sampled (Figure 2). Pyrosequencing revealed a richer bacterial community than clone library. In addition, pyrosequencing yielded Chao 1 and Shannon indices with higher values compared to clone library (Table 1). This indicates a richer and more diverse bacterial community, respectively. Furthermore, pyrosequencing generated a Simpson diversity index and evenness with lower values compared to clone library. Clearly, 454 pyrosequencing revealed a much more diverse bacterial community than clone library.

Bacteria, mostly Firmicutes and Proteobacteria, are introduced to the paper mill through contaminated cellulosic raw material, fresh incoming water and paper-making chemicals [2] [5]. Physical conditions in the paper mill range from basic to acidic $\mathrm{pH}$, ambient and high temperatures, aerobic and anaerobic environments, etc. 


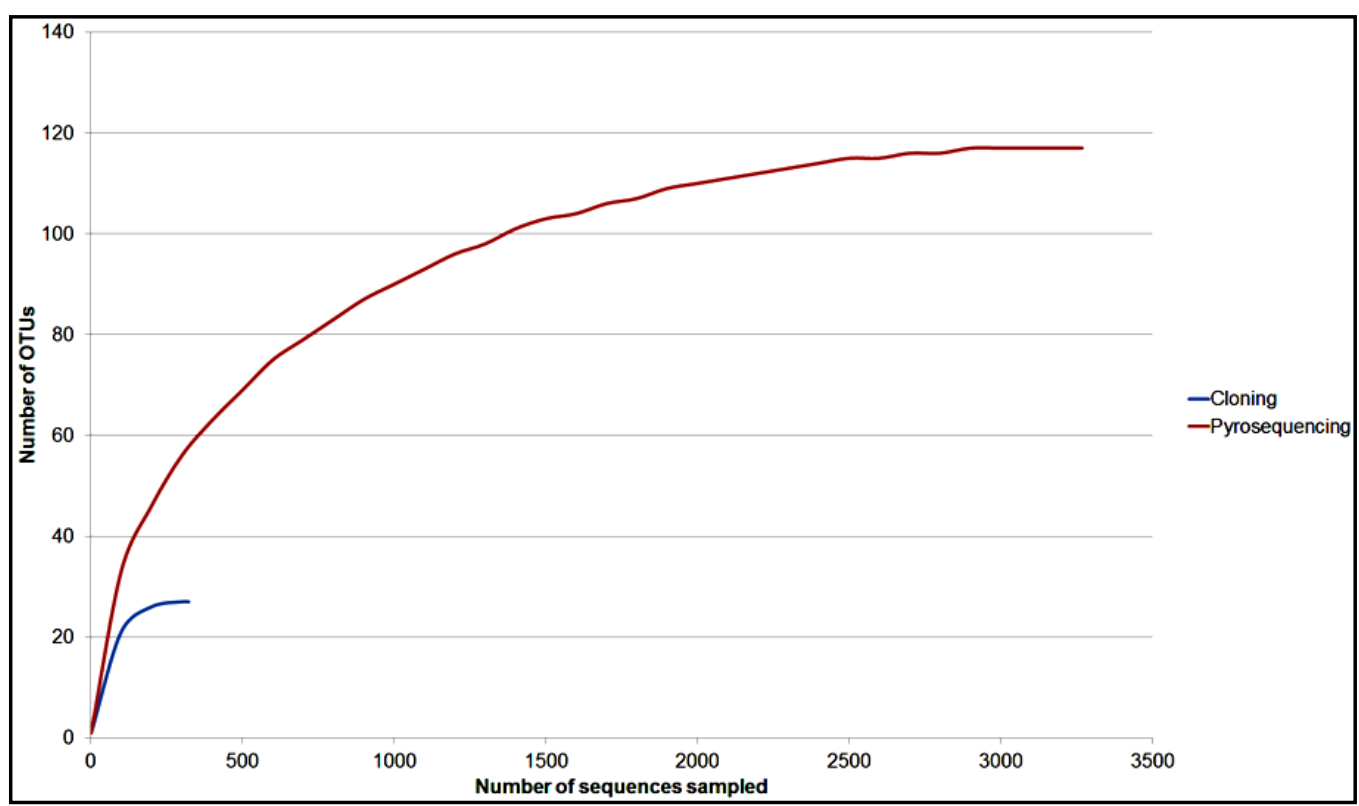

Figure 2. Rarefaction analysis of the bacterial sequences obtained from 454 pyrosequencing and clone library at the $97 \%$ similarity level.

Table 1. Comparison of the richness and diversity of the bacterial communities for the two approaches used (97\% similarity level).

\begin{tabular}{ccc}
\hline & 454 pyrosequencing & Clone library \\
\hline Accession numbers & SRR961674 & KF589334-KF589827 \\
Chao 1 richness & 117 & 27 \\
Shannon diversity index & 3.41 & 2.42 \\
Simpson diversity index & 0.06 & 0.14 \\
Evenness & 0.26 & 0.42 \\
\hline
\end{tabular}

Bacterial spores, owing to their resistance, will survive these very harsh environmental conditions and will be selected for. This leads to the accumulation and predominance of the spore-forming Firmicutes and the near absence of the much more sensitive non-spore-forming Proteobacteria. This was shown by Öqvist et al. [8] who found Bacillus and Enterococcus in white water. Disnard et al. [27] and Rättö et al. [28] both found Bacillus and Paenibacillus in biofilms. Suihko and Stackebrandt [29], Suominen et al. [30] and Väisänen et al. [31] all found Bacillus and Paenibacillus in final recycled food packaging paper and board. Suihkoand Stackebrandt [29] also found Bacillus silvestris, which has since been renamed Solibacillus silvestris [32], a genus present in our study. Likewise, McCusky Gendron et al. [11] and Namjoshi et al. [33] found Bacillus and Paenibacillus on unused paper towels and linerboard, respectively. Following use, some of these final recycled products will re-enter the recycling process. The bale of cardboard used in our study was a mix of cardboard collected from different sources. Most cardboard present in our bale had already gone through the recycling process several times, from the recycling plant to the paper mill, the production of the final recycled products, their various uses and back. The recycling plant is also a major source of microbial contamination. It receives paper, cardboard, glass, metal, plastic and textiles from domestic, industrial and commercial sources, some potentially soiled with food, grease and other organic residues, all substrates for microbial proliferation and accumulation. Following sorting, bales will most often be stored outdoors, under different meteorological and environmental conditions (rain, snow, wind, temperature, and the presence of small rodents and birds, etc.) for extended periods. This will most certainly lead to the formation of a much more complex and dynamic microbiota.

Ultimately, bales of cardboard ready to enter the paper mill for recycling have already been in contact with 
several potential sources of contamination. This is what we found herewith the presence of Firmicutes: Bacillus, Solibacillus and Paenibacillus, and the near absence of Proteobacteria in our bale of cardboard.

We are planning to follow up on this study by analyzing the bacterial community in other potential sources of contamination in a paper mill such as fresh incoming water and chemicals, additives and fillers. We will also study different bales of cardboard stored under various conditions. A better knowledge of their microbiota appears necessary to improve the storing conditions in order to reduce biofouling in the paper mill and ultimately to increase the quality of the final recycled products.

\section{Conclusion}

In conclusion, both methods, 454 pyrosequencing and clone library, showed the predominance of spore-forming Firmicutes in the bale of collected cardboard. However, pyrosequencing revealed a richer and more diverse bacterial community than clone library. The large number of steps in the recycling process, from the paper mill to the recycling plant and back, contributes to the bacterial microbiota revealed in this study.

\section{Acknowledgements}

This work was supported in part by the Natural Sciences and Engineering Research Council of Canada (grant EGP 436904-12). We thank Dong Xu for technical help with the cloning of PCR amplicons and Hassan Chadjaa and Kokou Adjallé for assistance in bale sampling. We thank Marie-Hélène Charest and Roger Gaudreault for helpful comments throughout the course of this study.

\section{References}

[1] Sorrelle, P.H. and Belgard, W.E. (1991) The Effect Of Recycled Fiber Use on Paper Machine Biological Control. TAPPI Proceedings, 569-575.

[2] Blanco, M.A., Negro, C., Gaspar, I. and Tijero, J. (1996) Slime Problems in Paper and Board Industry. Applied Microbiology and Biotechnology, 46, 203-220. http://dx.doi.org/10.1007/s002530050806

[3] Flemming, H.C., Meier, M. and Schild, T. (2013) Mini-Review: Microbial Problems in Paper Production. Biofouling, 29, 683-696. http://dx.doi.org/10.1080/08927014.2013.798865

[4] Milferstedt, K., Godon, J.J., Escudié, R., Prasse, S., Neyret, C. and Bernet, N. (2012) Heterogeneity and Spatial Distribution of Bacterial Background Contamination in Pulp and Process Water of a Paper Mill. Journal of Industrial Microbiology and Biotechnology, 39, 1751-1759. http://dx.doi.org/10.1007/s10295-012-1196-8

[5] Väisänen, O.M., Weber, A., Bennasar, A., Rainey, F.A., Busse, H.J. and Salkinoja-Salonen, M.S. (1998) Microbial Communities of Printing Paper Machines. Journal of Applied Microbiology, 84, 1069-1084. http://dx.doi.org/10.1046/j.1365-2672.1998.00447.x

[6] Desjardins, E. and Beaulieu, C. (2003) Identification of Bacteria Contaminating Pulp and a Paper Machine in a Canadian Paper Mill. Journal of Industrial Microbiology and Biotechnology, 30, 141-145.

[7] Suihko, M.L. and Skyttä, E. (2009) Characterisation of Aerobically Grown Non-Spore-Forming Bacteria from Paper Mill Pulps Containing Recycled Fibres. Journal of Industrial Microbiology Biotechnology, 36, 53-64. http://dx.doi.org/10.1007/s10295-008-0472-0

[8] Öqvist, C.K., Kurola, J., Pakarinen, J., Ekman, J., Ikävalko, S., Simell, J. and Salkinoja-Salonen, M. (2008) Prokaryotic Microbiota of Recycled Paper Mills with Low or Zero Effluent. Journal of Industrial Microbiology and Biotechnology, 35, 1165-1173. http://dx.doi.org/10.1007/s10295-008-0396-8

[9] Pellegrin, V., Juretschko, S., Wagner, M. and Cottenceau, G. (1999) Morphological and Biochemical Properties of a Sphaerotilus sp. Isolated from Paper Mill Slimes. Appliedand Environmental Microbiology, 65, 156-162.

[10] Oppong, D., King, V.M., Zhou, X. and Bowen, J.A. (2000) Cultural and Biochemical Diversity of Pink-Pigmented Bacteria Isolated from Paper Mill Slimes. Journal of Industrial Microbiology and Biotechnology, 25, 74-80. http://dx.doi.org/10.1038/sj.jim.7000036

[11] Gendron, L.M., Trudel, L., Moineau, S. and Duchaine, C. (2012) Evaluation of Bacterial Contaminants Found on Unused Paper Towels and Possible Postcontamination after Handwashing: A Pilot Study. American Journal of Infection Control, 40, e5-e9. http://dx.doi.org/10.1016/j.ajic.2011.07.007

[12] Väisänen, O.M., Nurmiaho-Lassila, E.L., Marmo, S.A. and Salkinoja-Salonen, M.S. (1994) Structure and Composition of Biological Slimes on Paper and Board Machines. Applied and Environmental Microbiology, 60, 641-653.

[13] Lahtinen, T., Kosonen, M., Tiirola, M., Vuento, M. and Oker-Blom, C. (2006) Diversity of Bacteria Contaminating Paper Machines. Journal of Industrial Microbiology and Biotechnology, 33, 734-740. 
http://dx.doi.org/10.1007/s10295-006-0105-4

[14] Granhall, U., Welsh, A., Throbäck, I.N., Hjort, K., Hansson, M. and Hallin, S. (2010) Bacterial Community Diversity in Paper Mills Processing Recycled Paper. Journal of Industrial Microbiology and Biotechnology, 37, 1061-1069. http://dx.doi.org/10.1007/s10295-010-0754-1

[15] Tiirola, M., Lahtinen, T., Vuento, M. and Oker-Blom, C. (2009) Early Succession of Bacterial Biofilms in Paper Machines. Journal of Industrial Microbiology and Biotechnology, 36, 929-937. http://dx.doi.org/10.1007/s10295-009-0571-6

[16] Woese, C.R. (1987) Bacterial Evolution. Microbiological Reviews, 51, 221-271.

[17] Hugenholz, P., Goebel, B.M. and Pace, N.R. (1998) Impact of Culture-Independent Studies on the Emerging Phylogenetic View of Bacterial Diversity. Journal of Bacteriology, 180, 4765-4774.

[18] Sogin, M.L., Morrison, H.G., Huber, J.A., Welch, D.M., Huse, S.M., Neal, P.R., Arrieta, J.M. and Herndl, G.J. (2006) Microbial Diversity in the Deep Sea and the Underexplored "Rare Biosphere". Proceedings of the National Academy of Sciences of the United States of America, 103, 12115-12120. http://dx.doi.org/10.1073/pnas.0605127103

[19] Comeau, A.M., Li, W.K.W., Tremblay, J.É., Carmack, E.C. and Lovejoy, C. (2011) Arctic Ocean Microbial Community Structure before and after the 2007 Record Sea Ice Minimum. PLoS ONE, 6, Article ID: e27492. http://dx.doi.org/10.1371/journal.pone.0027492

[20] Sanger, F., Nicklen, S. and Coulsonn, A.R. (1977) DNA Sequencing with Chain-Terminating Inhibitors. Proceedings of the National Academy of Sciences of the United States of America, 74, 5463-5467.

[21] Schloss, P.D. (2009) A High-Throughput DNA Sequence Aligner for Microbial Ecology Studies. PLoS ONE, 4, Article ID: e8230. http://dx.doi.org/10.1371/journal.pone.0008230

[22] Schloss, P.D., Westcott, S.L., Ryabin, T., Hall, J.R., Hartmann, M., Hollister, E.B., Lesniewski, R.A., Oakley, B.B., Parks, D.H., Robinson, C.J., Sahl, J.W., Stres, B., Thallinger, G.G., Van Horn, D.J. and Weber, C.F. (2009) Introducing Mothur: Open Source, Platform-Independent, Community-Supported Software for Describing and Comparing Microbial Communities. Applied and Environmental Microbiology, 75, 7537-7541. http://dx.doi.org/10.1128/AEM.01541-09

[23] Comeau, A.M., Harding, T., Galand, P.E., Vincent, W.F. and Lovejoy, C. (2012) Vertical Distribution of Microbial Communities in a Perennially Stratified Arctic Lake with Saline, Anoxic Bottom Waters. Scientific Reports, 2, Article No. 604. http://dx.doi.org/10.1038/srep00604

[24] Quast, C., Pruesse, E., Yilmaz, P., Gerken, J., Schweer, T., Yarza, P., Peplies, J. and Glöckner, F.O. (2013) The SILVA Ribosomal RNA Gene Database Project: Improved Data Processing and Web-Based Tools. Nucleic Acids Research, 41, D590-D596. http://dx.doi.org/10.1093/nar/gks1219

[25] DeSantis, T.Z., Hugenholtz, P., Larsen, N., Rojas, M., Brodie, E.L., Keller, K., Huber, T., Dalevi, D., Hu, P. and Andersen, G.L. (2006) Greengenes, a Chimera-Checked 16S rRNA Gene Database and Workbench Compatible with ARB. Applied and Environmental Microbiology, 72, 5069-5072. http://dx.doi.org/10.1128/AEM.03006-05

[26] Werner, J.J., Koren, O., Hugenholtz, P., DeSantis, T.Z., Walters, W.A., Caposaro, J.G., Angenent, L.T., Knight, R. and Ley, R.E. (2012) Impact of Training Sets on Classification of High-Throughput Bacterial 16S rRNA Gene Surveys. The International Society for Microbial Ecology Journal, 6, 94-103.

[27] Disnard, J., Beaulieu, C. and Villemur, R. (2011) Composition of the Bacterial Biota in Slime Developed in Two Machines at a Canadian Paper Mill. Canadian Journal of Microbiology, 57, 91-104. http://dx.doi.org/10.1139/W10-109

[28] Rättö, M., Suihko, M.L. and Siika-aho, M. (2005) Polysaccharide-Producing Bacteria Isolated from Paper Machine Slime Deposits. Journal of Industrial Microbiology and Biotechnology, 25, 109-114. http://dx.doi.org/10.1007/s10295-005-0210-9

[29] Suihko, M.L. and Stackebrandt, E. (2003) Identification of Aerobic Mesophilic Bacilli Isolated from Board and Paper Products Containing Products Containing Recycled Fibres. Journal of Applied Microbiology, 94, 25-34. http://dx.doi.org/10.1046/j.1365-2672.2003.01803.x

[30] Suominen, I., Suihko, M.L. and Salkinoja-Salonen, M. (1997) Microscopic Study of Migration of Microbes in FoodPackaging Paper and Board. Journal of Industrial Microbiology and Biotechnology, 19, 104-113. http://dx.doi.org/10.1038/sj.jim.2900424

[31] Väisänen, O.M., Mentu, J. and Salkinoja-Salonen, M. (1991) Bacteria in Food Packaging Paper and Board. Journal of Applied Bacteriology, 71, 130-133. http://dx.doi.org/10.1111/j.1365-2672.1991.tb02967.x

[32] Krishnamurthi, S., Chakrabarti, T. and Stackebrandt, E. (2009) Re-Examination of the Taxonomic Position of Bacillus silvestris Rheims et al. 1999 and Proposal to Transfer It to Solibacillus gen. nov. as Solibacillus silvestris comb. nov. International Journal of Systematic and Evolutionary Microbiology, 59, 1054-1058.

[33] Namjoshi, K., Johnson, S., Montello, P. and Pullman, G.S. (2010) Survey of Bacterial Populations Present in US-Produced Linerboard with High Recycle Content. Journal of Applied Microbiology, 108, 416-427.

http://dx.doi.org/10.1111/j.1365-2672.2009.04437.x 
Scientific Research Publishing (SCIRP) is one of the largest Open Access journal publishers. It is currently publishing more than 200 open access, online, peer-reviewed journals covering a wide range of academic disciplines. SCIRP serves the worldwide academic communities and contributes to the progress and application of science with its publication.

Other selected journals from SCIRP are listed as below. Submit your manuscript to us via either submit@scirp.org or Online Submission Portal.
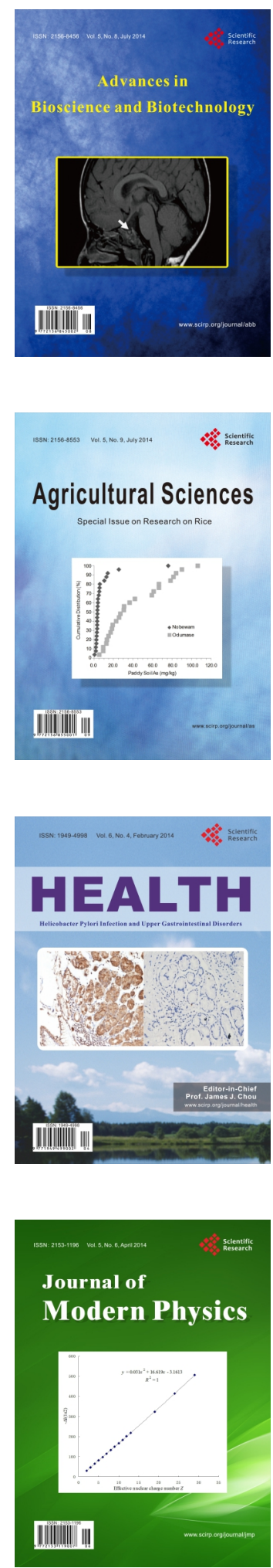
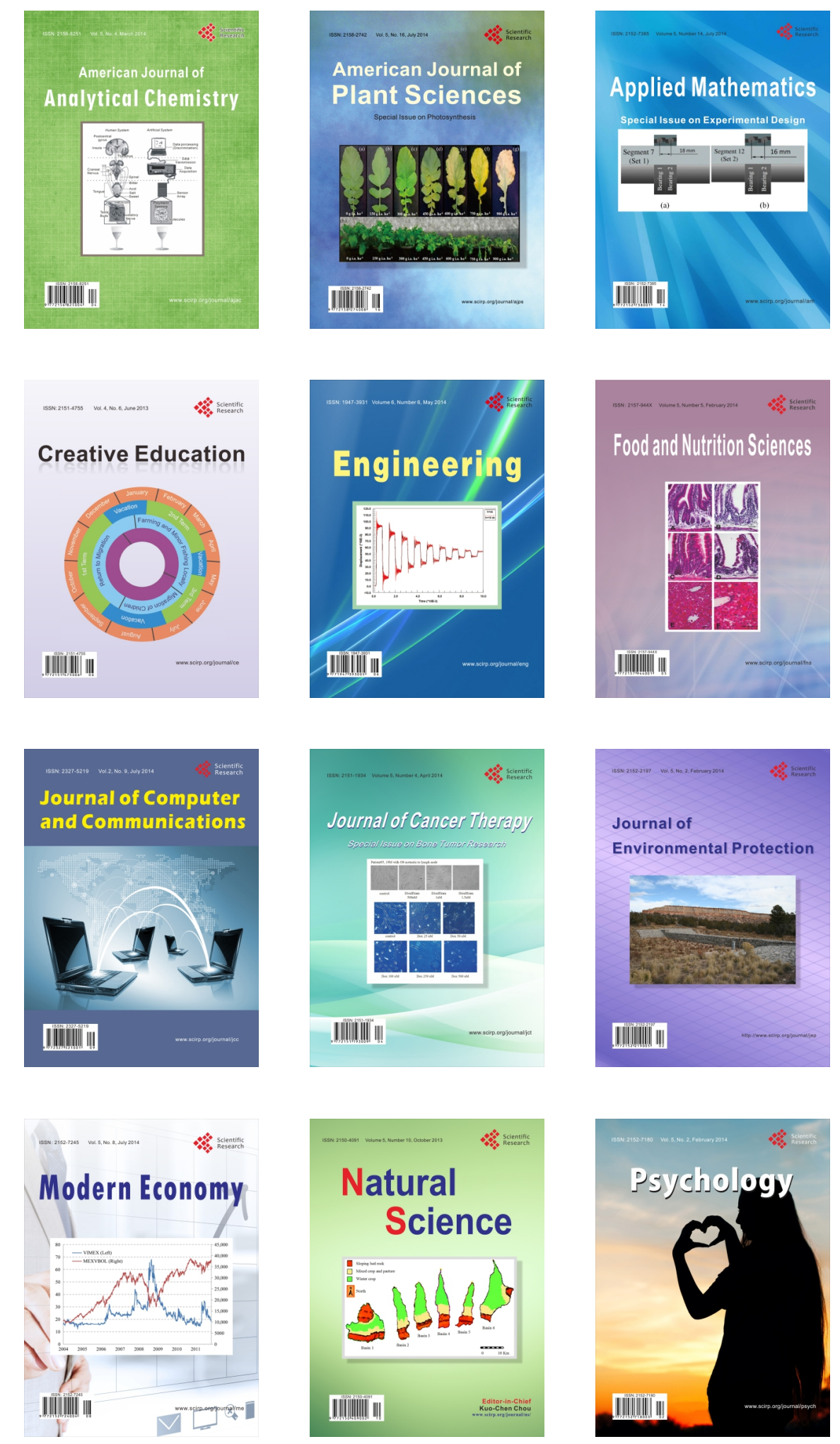